\title{
Ocotea nutans (Nees) Mez (Lauraceae): chemical composition, antioxidant capacity and biological properties of essential oil
}

\author{
Fernando Cesar Martins Betim ${ }^{1 *}$, Camila Freitas de Oliveira ${ }^{\mathbf{1}}$, Angela Maria de Souza ${ }^{\mathbf{1}}$, \\ Ellis Marina Szabo', Sandra Maria Warumby Zanin'1, Obdulio Gomes Miguel'1, \\ Marilis Dallarmi Miguel' ${ }^{1}$, Josiane de Fátima Gaspari Dias ${ }^{1}$
}

\author{
'Postgraduate Program in Pharmaceutical Sciences, Federal University of Paraná, Curitiba, PR, Brazil
}

\begin{abstract}
The present study was undertaken to assess the potential uses of the essential oil obtained from Ocotea nutans (Nees) Mez. The hydrodistilled essential oil from O. nutans leaves was analyzed by gas chromatography-mass spectrometry. Fifty-eight compounds representing $87,29 \%$ of the total leaf essential oil components were identified, of which biciclogermacrene $(11.41 \%)$, germacrene-D (4.89\%), bisabolol$11-o l(3.73 \%)$ and spathulenol $(3.71 \%)$ were the major compounds. The essential oil from O. nutans were tested for antibacterial activity using the minimum inhibitory concentracion (MIC) method, Artemia salina method, larvicidal activity in Aedes aegypti, and antioxidant capacity. The antioxidant activity measured by the phosphomolybdenum complex and Prussian blue method had positive results. The minimum inhibitory concentration for the microorganisms tested allowed moderate inhibitionfor Enterococcus faecalis $(\mathrm{MIC}=500 \mu \mathrm{g} / \mathrm{mL})$. Artemia salina were toxic to the organisms in the study $\left(\mathrm{LC}_{50}=71,70 \mu \mathrm{g} / \mathrm{mL}\right)$. The essential oil showed remarkable larvicidal activity potencial $\left(\mathrm{LC}_{50}=250 \mu \mathrm{g} / \mathrm{mL}\right)$. The present results showed that $O$. nutans essential oil has potential biological uses.
\end{abstract}

Keywords: Ocoteanutans/essential oil/evaluation. Antioxidant capacity.Aedesaegypti.Toxic potential.

\section{INTRODUCTION}

Lauraceae is a family of flowering plants that contain approximately 2,500 species distributed in the Neotropics of America and several species found in Africa and Madagascar (Van der Werff, 2002). This family has great economic importance, with several species (particularly from the genera Ocotea, Nectandra and Aniba) having high commercial value because they are aromatic plants that produce essential oils commonly used in different industries (Marques, 2001). Ocotea is one of the largest genus of the family Lauraceae that is located in America. This genus includes approximately 350 species distributed in tropical and subtropical America (from Argentina to México). In Brazil, there are approximately 150 species of Ocotea. According to a study by Brotto, Cervi and Santos(2013), 31 species of Ocotea occur in Paraná State (Brazil), with the Atlantic Forest having the highest number of species (26), followed by the Araucaria Forest (14 species) with an endemic seasonal (11 species) and theCerrado ( 7 species )

\footnotetext{
*Correspondence: F. C. M.Betim. Programa de Pós-graduação em Ciências Farmacêuticas, Universidade Federal do Paraná, Curitiba, PR, Brasil. Phone: +55 41 3360-4070. E-mail: fernandobetim@hotmail.com iD
}

with two endemic and fields (1 specie).

Ocotea nutans (Ness) Mez (Lauraceae) is a 10-30 meter high tree, that is found in the Mixed Ombrophilus Forest, often distributed in the first and second plateau (Brotto, Cervi, Santos, 2013). This species is popularly named 'canelinha' and 'canela'.

Essential oils from the genus Ocotea have evidenced pharmacological effects:e.g., cardiovascular (BarbosaFilho et al., 2008), antifungal and antibacterial (Garrett et al., 2007), anti-inflammatory (Ballabeni et al., 2010) and antiplatelet (Ballabeni et al., 2007) activities.

In the present study, the chemical composition of essential oils from leaves of $O$. nutans were examined by gas chromatography-mass spectrometry (GC-MS), the evaluation of antioxidant activity was undertaken, and testing of potencial biological activities (antibacterial, toxicological and larvicidal properties) occured.

\section{MATERIAL AND METHODS}

\section{Plant material}

The leaves of $O$. nutans were collected from the 
city of Colombo, Paraná State, Brazil (2517’03.5”S, $49^{\circ} 08^{\prime} 44^{\prime}$ 'W). Plant identification was performed by forest engineer Marcelo Leandro Brotto, from the Botanical Garden of Curitiba Herbarium by comparison with the voucher specimen deposited under number 56552 at the Herbarium of the Federal University of Paraná.

The present study was authorized by the Genetic Heritage Management Council (CGEN), a legislative and deliberative body under the Ministry of the Environment of Brazil, under number 02001.001165 / 2013-47.

\section{Extraction of essential oil}

The essential oil was extracted from $100 \mathrm{~g}$ of dried leaves that had been ground in a knife mill and hydrodistilled for $6 \mathrm{~h}$ using a modified Clevenger type apparatus. The essential oil was stored in a sealed amber jar glass at $-18^{\circ} \mathrm{C}$ until subsequent analysis. The essential oil yield was expressed in $\mathrm{v} / \mathrm{w} \%$ of essential oil per $100 \mathrm{~g}$ of the drug (Brasil, 2010).

\section{Gas chromatography-mass spectrometry (GC-MS) analysis}

The essential oil from $O$. nutans was analyzed by gas chromatography-mass spectrometry using a Shimadzu GC-MS - QP 2010 Plus analyzer equipped with a capillary column Rtx $-5 \mathrm{MS}(30 \mathrm{~m} \times 0.25 \mathrm{~mm} \times 0.25 \mu \mathrm{m}$.) with a splitless injector mode at $250{ }^{\circ} \mathrm{C}$, and an ion source and interface at $300{ }^{\circ} \mathrm{C}$. The mass window was analyzed from $\mathrm{m} / \mathrm{z} 40$ and $\mathrm{m} / \mathrm{z} 350$, using helium as the carrier gas. Ramp injection for analysis had the injector temperature set at $250{ }^{\circ} \mathrm{C}$, pressure of $20 \mathrm{psi}$ column, starting at $50{ }^{\circ} \mathrm{C}$ for $5 \mathrm{~min}$ and increasing to $200^{\circ} \mathrm{C}$ at a rate of $5^{\circ} \mathrm{C} / \mathrm{min}$. Identification of the oil components was undertaken by comparing their Kovats indices and mass spectra with the NIST library as well as comparing them with those reported in the literature (Adams, 2007).

\section{Antioxidant activity of essential oil}

\section{Formation of the phosphomolybdenum complex method}

The essential oil and standard (ascorbic acid and rutin) were diluted in methanol to a concentration of $200 \mu \mathrm{g} / \mathrm{mL}$. The methodology used has been described previously by Prieto, Pineda and Aguilar (1999). A $0.3 \mathrm{~mL}$ essential oil was combined with $1 \mathrm{~mL}$ of reagent solution $(0.1 \mathrm{~mol} / \mathrm{L}$ of sodium phosphate, $0.03 \mathrm{~mol} / \mathrm{L}$ of ammonium molybdate and $3 \mathrm{~mol} / \mathrm{L}$ of sulfuric acid) and made up to $100 \mathrm{~mL}$ with distilled water. The tubes were incubated at
$95{ }^{\circ} \mathrm{C}$ for $90 \mathrm{~min}$, after which they were cooled to room temperature $\left(25-30{ }^{\circ} \mathrm{C}\right)$. The absorbance of the solution was measured at $695 \mathrm{~nm}$. The AA\% compared to ascorbic acid was evaluated with the following formula:

$$
\begin{aligned}
& \mathrm{AA} \% \text { compared to ascorbic acid }=\left[\left(A_{\text {sample }}-A_{\text {blank }}\right) /\right. \\
& \left(A_{\text {control }}\right)-\left(A_{\text {blank }}\right] \times 100
\end{aligned}
$$

where $A_{\text {sample }}$ is the absorbance of the test compound, $A_{\text {blank }}$ is the absorbance of the white and $A_{\text {control }}$ is the absorbance of the ascorbic acid.

\section{Reducing power antioxidant (Prussian blue) method}

In the antioxidant activity test (Prussian blue method), the essential oil at a concentration of $200 \mu \mathrm{g} / \mathrm{mL}$ was transferred to $25 \mathrm{~mL}$ test tubes, and $0.2 \mathrm{M}$ potassium phosphate buffer $(\mathrm{pH} 7.0)$ and $1.0 \%$ potassium ferricyanide were added. The mixture was incubated at $45^{\circ} \mathrm{C}$ for $20 \mathrm{~min}$, and then $1 \%$ trichloroacetic acid was added to the test tubes. Approximately $2.5 \mathrm{~mL}$ was transferred to $5.0 \mathrm{~mL}$ test tubes, and $1.5 \mathrm{~mL}$ of distilled $\mathrm{H}_{2} \mathrm{O}, 1.0 \mathrm{~mL}$ of ethanol and $0.5 \mathrm{~mL}$ of $\mathrm{FeCl}_{3}$ was added to make up to $1.0 \%$ $(\mathrm{w} / \mathrm{v})$. The absorbance reading was performed at $700 \mathrm{~nm}$ (Yen, Chen, 1995;Jayanthi,Lalitha, 2011).

\section{Antibacterial activity}

The antibacterial activity tests were performed with the following strains: Enterococcus faecalis (ATCC 29212), Staphylococcus aureus (ATCC 25923), Staphylococcus epidermidis (ATCC 12228), Escherichia coli (ATCC 25922), Klebsiella pneumoniae (ATCC 700603 ) and Pseudomonas aeruginosa (ATCC 27853).

The essential oil was prepared in $0.5 \%$ of polysorbate 80 , and filtered through a $0.22 \mu \mathrm{m}$ Milipore membrane (TPP, Trasadingen, Switzerland) to assure its sterility. The suspensions of bacteria were prepared in saline solution at a concentration of $10 \times 10^{8} \mathrm{CFU} / \mathrm{mL}$, corresponding to a $0.5 \mathrm{McF}$ arland standard tube.

The minimum inhibitory concentration (MIC) values were determined through broth microdilution method (Clinical and Laboratory Standards Institute, 2008). The essential oil was tested at concentrations from 7.81 to $1000 \mu \mathrm{g} / \mathrm{mL}$ in microplates containing Muller Hinton Broth and $5 \mu 1$ suspensions of bacteria were subsequently inoculated into the wells to obtain a final concentration of $10^{4} \mathrm{CFU} / \mathrm{mL}$. After preparation, the microplates were incubated at $35^{\circ} \mathrm{C}$ for 16 to $20 \mathrm{~h}$. After this time, $20 \mu \mathrm{L}$ of aqueous solution of $0.5 \%$ triphenyltetrazolium chloride (Merck, Darmstadt, Gemany) was added, and the microplates were incubated again for $3 \mathrm{~h}$ at $35^{\circ} \mathrm{C}$ (Souza et al., 2014) 
The red color formation in the microplate wells were evaluated as the absence of bacterial growth inhibition. The MIC values obtained were classified as having good inhibitory potential (up to $100 \mu \mathrm{g} / \mathrm{mL}$ ), moderate inhibitory activity (between 100 and $500 \mu \mathrm{g} / \mathrm{mL}$ ), weak inhibitory activity (between 500 and $1000 \mu \mathrm{g} / \mathrm{mL}$ ), and absence of inhibitory activity (higher than $1000 \mu \mathrm{g} / \mathrm{mL}$ ) (Ayres et al., 2008).

\section{Preliminary toxicological activities}

\section{Toxicity against Aedes aegypti}

The methodology applied was adapted from the World Health Organization (2005) and Fujiwara et al. (2017). The eggs of Aedes aegypti (eggs from the Rockefeller strain made available by Oswaldo Cruz Foundation - Fiocruz) were placed in dechlorinated water and incubated in a B.O.D incubator at a controlled temperature of $27^{\circ} \mathrm{C}$ and relative humidity of $80 \%$. The larval diet consisted of fish feed (Aldon basic, MEP 200 complex), from hatching until they reach the third developmental larval stage.

The essential oil was diluted in $0.5 \%$ of polysorbate 80 , and then dissolved in dechlorinated water to obtain the desired concentration. An aqueous solution of $0.5 \%$ of polysorbate 80 was used as a negative control and the insecticide temephos was use as a positive control. The positive control was used at a concentration of $6 \mu \mathrm{g} / \mathrm{mL}$ (twice the lethal concentration that causes $99 \%$ mortality of susceptible strains) according to the protocol recommended (WHO, 1981; Lima et al., 2003; Grzybowski et al., 2012).

After hatching, 10 larvae in the 3rd stage were placed in contact with the negative and positive control and essential oil at concentrations $(1000,500,100$ and $10 \mu \mathrm{g} /$ $\mathrm{mL}$ ) for $24 \mathrm{~h}$ and then live and dead larvae were counted. Three repetitions were used for each treatment giving a total of 30 larvae to each sample dose.

\section{Brine shrimp (Artemia salina) lethality assay}

The essential oil was diluted in $0.5 \%$ of polysorbate 80 and then dissolved in artificial seawater to obtain the desired concentration. Artificial seawater and $0.5 \%$ of polysorbate 80 , was used as the negative control, and sodium dodecyl sulfatewas used as the positive control (Amarante et al., 2011). The assay was performed according to the methodology described by Meyer et al. (1982) with modifications. The eggs of Artemia salina L. were placed in artificial seawater ( $38 \mathrm{~g}$ marine salts dissolved in $1000 \mathrm{~mL}$ purified water) and incubated in a B.O.D. incubator at controlled temperature of $(30 \pm 2){ }^{\circ} \mathrm{C}$ for $48 \mathrm{~h}$. After hatching, 10 nauplii of Artemia salina $\mathrm{L}$. were placed in contact with the negative and posite control and essential oil at concentrations $(1000,500,250$, 100 and $10 \mu \mathrm{g} / \mathrm{mL}$ ) for $24 \mathrm{~h}$, and then the live and dead nauplii were counted. Three replicates were used for each treatment, totaling 30 nauplii for each sample dose. The positive control was used in concentrations of 10, 20,30, 40 and50 $\mu \mathrm{g} / \mathrm{mL}$.

\section{Statistical analysis}

The probit method (Finney, 1971) was used to determine the lethal concentration $\left(\mathrm{LC}_{50}\right.$ and $\left.\mathrm{LC}_{90}\right)$ values, as well as the corresponding $95 \%$ confidence intervals and chi square values for the assays with Aedes aegypti and Artemia salina L., using the IBM SPSS Statistics version 20.0 software program.

\section{RESULTS AND DISCUSSION}

\section{Chemical composition of the essential oil}

GC-MS analysis of the essential oil led to the identification of 58 different compounds, representing $87,29 \%$ of the total oil from the leaves. The identified compounds are listed in Table I, according to their elution order on the capillary column.

Essential oil is a mixture of volatile, lipophilic, odoriferous and liquid substances (Simões et al.,2004). Chemically the essential oil was composed of terpene hydrocarbons, simple alcohols and terpenes, aldehydes, ketones, phenols, esters, oxides, peroxides, furans, organic acids, lactones, coumarins and sulfur containing compounds, with different concentrations. Among these, the most representative group were the terpenoids, which are formed by the fusion of isoprene units of five carbons, and when subjected to high temperatures, might decompose into isoprenes and occasionally refer to all terpenoids as isoprenoids (Taiz, Zeiger, 2004). Terpenoids are considered a homogeneous group owing to the presence of the isoprene units $\left(-\mathrm{C}_{5} \mathrm{H}_{8}\right)$, which form hemiterpenes, monoterpenes, sesquiterpenes, diterpenes, triterpenes and tetraterpenes (Castro et al., 2004; Simões et al., 2004; Brielmann et al. 2006).

The essential oils of plants have specific compositions, and in the genus Ocotea there is a predominance of monoterpenes and sesquiterpenes, which are often present in several species of the same genus, in varying amounts and sometimes may or may not be present in some species (Bruni et al., 2004; Coutinho et al., 2007; Barbosa-Filho et al., 2008). 
TABLE I - Chemical compounds identified in analysis GC-MS of Ocotea nutans essencial oil

\begin{tabular}{|c|c|c|c|c|}
\hline COMPOUNDS* & $\begin{array}{l}\text { CHEMICAL } \\
\text { CLASS }\end{array}$ & $\mathbf{R} \mathbf{I}^{\mathbf{a}}$ & $\begin{array}{c}\% \\
\text { RA }^{\text {b }}\end{array}$ & Identification $^{c}$ \\
\hline$\overline{\text { Pinene }<\alpha->}$ & $\mathrm{M}$ & 939 & 2.12 & RI, MS \\
\hline Camphene & M & 954 & 0.09 & RI, MS \\
\hline Sabinene & M & 975 & 0.16 & RI, MS \\
\hline Pinene $<\beta->$ & M & 979 & 2.81 & RI, MS \\
\hline Myrcene & M & 990 & 1.13 & RI, MS \\
\hline Terpinene $<\alpha->$ & M & 1017 & 0.07 & RI, MS \\
\hline Limonene & M & 1029 & 3.24 & RI, MS \\
\hline Cineole $<1,8->$ & $\mathrm{OM}$ & 1031 & 0.61 & RI, MS \\
\hline Ocimene $<(Z)-\beta->$ & M & 1037 & 0.09 & RI, MS \\
\hline Ocimene $<(E)-\beta->$ & M & 1050 & 0.09 & RI, MS \\
\hline Terpinene $<\boldsymbol{\gamma}->$ & M & 1059 & 0.16 & RI, MS \\
\hline Terpinolene & M & 1088 & 0.10 & RI, MS \\
\hline Linalool & $\mathrm{OM}$ & 1096 & 0.18 & RI, MS \\
\hline Camphor & $\mathrm{OM}$ & 1146 & 0.16 & RI, MS \\
\hline Terpinen-4-ol & $\mathrm{OM}$ & 1177 & 0.72 & RI, MS \\
\hline Terpineol $<\alpha->$ & OS & 1188 & 0.70 & RI, MS \\
\hline Elemene $<\delta$ - $>$ & S & 1338 & 1.32 & RI, MS \\
\hline Cubebene $<\alpha->$ & S & 1348 & 1.11 & RI, MS \\
\hline Ylangene $<\alpha->$ & S & 1376 & 0.33 & RI, MS \\
\hline Copaene $<\alpha->$ & S & 1376 & 2.20 & RI, MS \\
\hline Burbonene $<\beta->$ & $\mathrm{S}$ & 1388 & 0.78 & RI, MS \\
\hline Elemene $<\beta->$ & $\mathrm{S}$ & 1390 & 1.94 & RI, MS \\
\hline Gurjunene $<\alpha->$ & S & 1409 & 0.27 & RI, MS \\
\hline Caryophyllene $<(\mathrm{E})->$ & S & 1419 & 2.47 & RI, MS \\
\hline Copaene $<\beta->$ & $\mathrm{S}$ & 1432 & 0.38 & RI, MS \\
\hline Guaiene $<\alpha->$ & S & 1439 & 0.89 & RI, MS \\
\hline Guaiadiene $<6,9->$ & S & 1444 & 0.44 & RI, MS \\
\hline Muurola-3,5-diene $<$ cis- $>$ & S & 1450 & 2.09 & RI, MS \\
\hline Humulene $<\alpha->$ & $\mathrm{S}$ & 1454 & 1.89 & RI, MS \\
\hline Aromadendrene $<$ allo- $>$ & S & 1460 & 3.22 & RI, MS \\
\hline Cadina-1(6),4-diene $<$ trans- $>$ & S & 1476 & 1.71 & RI, MS \\
\hline Muurolene $<\gamma->$ & S & 1479 & 1.13 & RI, MS \\
\hline Germacrene D & $\mathrm{S}$ & 1485 & 4.89 & RI, MS \\
\hline Selinene $<\beta->$ & S & 1490 & 0.72 & RI, MS \\
\hline Muurola-4(14),5-diene $<$ trans- $>$ & S & 1493 & 3.09 & RI, MS \\
\hline Bicyclogermacrene & S & 1500 & 11.41 & RI, MS \\
\hline Amorphene $<\delta$ - $>$ & $\mathrm{S}$ & 1512 & 1.01 & RI, MS \\
\hline Cadinene $<\gamma->$ & S & 1513 & 3.13 & RI, MS \\
\hline Cadina-1,4-diene $<$ trans- $>$ & $\mathrm{S}$ & 1534 & 1.84 & RI, MS \\
\hline Cadinene $<\alpha->$ & S & 1538 & 0.31 & RI, MS \\
\hline Calacorene $<\alpha->$ & $\mathrm{S}$ & 1545 & 0.24 & $\mathrm{RI}, \mathrm{MS}$ \\
\hline
\end{tabular}


Ocotea nutans (Nees) Mez (Lauraceae): chemical composition, antioxidant capacity and biological properties of essential oil

TABLE I - Chemical compounds identified in analysis GC-MS of Ocotea nutans essencial oil (cont.)

\begin{tabular}{lcccc}
\hline COMPOUNDS* & $\begin{array}{c}\text { CHEMICAL } \\
\text { CLASS }\end{array}$ & RI $^{\mathbf{a}}$ & $\begin{array}{c}\mathbf{\%}^{\mathbf{b}} \\
\mathbf{R A}^{\mathbf{b}}\end{array}$ & Identification $^{\mathbf{c}}$ \\
\hline Elemol & OS & 1549 & 0.62 & RI, MS \\
Germacrene B & S & 1561 & 0.44 & RI, MS \\
Nerolidol<(E)-> & OS & 1563 & 0.56 & RI, MS \\
Palustrol & OS & 1568 & 0.28 & RI, MS \\
Germacrene D-4-ol & OS & 1575 & 0.53 & RI, MS \\
Spathulenol & OS & 1578 & 3.71 & RI, MS \\
Caryophyllene oxide & OS & 1583 & 1.74 & RI, MS \\
Globulol & OS & 1590 & 2.45 & RI, MS \\
Ledol & OS & 1602 & 0.80 & RI, MS \\
Cubenol<1,10-di-ep-i> & OS & 1619 & 2.50 & RI, MS \\
Cadin-4-en-7-ol<cis-> & OS & 1636 & 0.72 & RI, MS \\
Muurolol< $<->$ & OS & 1646 & 3.18 & RI, MS \\
Valerianol & OS & 1658 & 0.77 & RI, MS \\
Eudesmol<dihydro-> & OS & 1662 & 2.29 & RI, MS \\
Bisabol-11-ol <(E)-> & OS & 1668 & 3.73 & RI, MS \\
Rosa-5,15-diene<ent-> & D & 1934 & 0.38 & RI, MS \\
Kaurene & D & 2043 & 0.55 & RI, MS \\
Total (identified) & & & 87.29 & \\
(M) Monoterpene hydrocarbon (11) & & & $10.06 \%$ & \\
(OM) Oxygenated monoterpene (5) & & & $2.37 \%$ & \\
(S) Sesquiterpene hydrocarbons (26) & & & $23.88 \%$ & \\
(OS) Oxygenated sesquiterpene (14) & & & & \\
(D) Diterpenes (2) & & & & \\
\hline
\end{tabular}

The terpene compounds of several species of Ocotea, have as its major components: $\alpha$-Pinene, $\beta$-Pinene, $\beta$-Elemene, $\beta$-Caryophyllene, $\alpha$-Humulene, Germacrene D, $\gamma$-Cadinene, $\delta$-Cadinene and $\alpha$-Cadinol (Takaku, Haber, Setzer, 2007). Moreover these nine compounds are common to other genera in the family Lauraceae such as Cinnamomum, Laurus, Aniba, Nectandra and Persea. These compounds were found in the essential oil fromO.nutans which reveals the close chemotaxonomic relationship between $O$. nutans and other species of Ocotea belonging to the first group of chemical diversity (one whose species contain terpenes compounds). This is typical of the essential oils of several Ocotea species from South America (Chaverri et al., 2011).

The essential oil from O.nutans presented sesquiterpenes as another major constituent which could be related to the antibacterial activity detected. Although the essential oil is a complex mixture of metabolites, this activity might influence the composition of the major components.

Another major compound identified in the essential oil from O.nutans was bicyclogermacrene (11.41\%). The bicyclogermacrene is effective in microbiological activities (Constantin et al., 2001). Germacrene-D showed anti-cancer activity (Sylvestre et al., 2006), antibacterial activity (Deuschle et al., 2007) and insectifugal (Frascescato, 2007). Bisabol-11-ol showed a known pharmacological activity and is used as an antiinflammatory agent (Robbers, Speedie, Tyler, 1997), for wound healing, and also as anatimicrobial (Darra et al., 2008). Spathulenol has atimicrobial properties (VeigaJunior, Pinto, 2002; Limberger et al., 2004). Limonene has proven effective in anti-inflammatory activities (Hirota et al., 2010), for gastroprotection (Rozzaet al., 2011), chemopreventive activity for liver, lung, skin and breast cancers (Crowell,1997) and as an atininociceptive (Amaral et al., 2007; Murali, Saravanan, 2012). Allo- 
aromadendrene has antibacterial activity (Scalco et al., 2014).

The $0,54 \%(\mathrm{v} / \mathrm{w})$ yield of the O.nutans essential oil was good when compared to other species of the same genus: O. notata $0,12 \%(\mathrm{v} / \mathrm{w})$ (Garrett et al.,2007), O. leucoxylon $0.13 \%(\mathrm{v} / \mathrm{w})$, O. minor $0.11 \%(\mathrm{v} / \mathrm{w})$ (Yamaguchi, 2011), and $O$. nigrescens $0.23 \%(\mathrm{v} / \mathrm{w})$, however, it was lower than the yield fromO. odorifera $0,86 \%(\mathrm{v} / \mathrm{w})$ (Castellani et al., 2006).Environmental factors that the plants species are subjected to (e.g., natural factors, light, temperature and humidity), botanical origin, and chemotype, have been demonstrated to significantly influence the emission of volatile compounds, altering their yield and composition (Simões et al., 2004).

\section{Antioxidant activity of essential oil}

The ability to reduce a fraction serves as an indicator of its antioxidant potential. Evaluation of the antioxidant activity by the reducing power method (Prussian blue) allowed the antioxidant potential of the $O$. nutans essential oil to be verified. The standards used for comparison were ascorbic acid and rutin.

The analytical method based on $\mathrm{Fe}^{3+}$ reduction, that determines the reducing power was applied to evaluate antioxidant activity. This method is based on the capacity of phenolic compounds to reduce $\mathrm{Fe}^{3+}$, with consequent formation of a colored complex with $\mathrm{Fe}^{2+}$. The ferricyanide ion is reduced to ferrocyanide which, in the presence of the ferric ion (from $\mathrm{FeCl}_{3}$ ), forms the complex of Prussian blue, $\mathrm{Fe}_{4}\left[\mathrm{Fe}(\mathrm{Cn}){ }_{6}\right]_{3}($ Yen, Chen, 1995; Jayanthi; Lalitha, 2011).

The antioxidant activity measured by the formation of the phosphomolybdenum complex is described in Table II. This method measures the inhibition of ammonium molybdate by the action of the essential oil which is based on the reduction of molybdenum IV to molybdenum $\mathrm{V}$ and subsequently the formation of a green complex corresponding to phosphate/molybdenum $\mathrm{V}$ in acid $\mathrm{pH}$. The assay is undertaken at an elevated temperature for a prolonged period and has the advantage of evaluating antioxidant capacity in both lipophilic substances and hydrophilic substances in an acid medium (Prieto, Pineda,
Aguilar, 1999).

The differences between the results obtained by the two techniques might be associated with the action mechanisms involved in the methods and the hydro/ lipophilicity of the antioxidant substances present in the essential oil.

\section{Antibacterial activity}

This is the first known study of showing the antibacterial activity of essential oil from O.nutans. The essential oil has constituents that could be considered as having antibacterial activity. The activity in vitro effects of the essential oil were measured in the present study. The values obtained from the microbiological assays were $\mathrm{MIC}=500 \mu \mathrm{g} / \mathrm{mL}$ in E. faecalis and MIC $=1000 \mu \mathrm{g} / \mathrm{mL}$ for $S$. aureus, $S$ epidermidis and $P$ aeruginosa. No activity was observed for $E$. coli and $K$. pneumoniae.

A study carried out with the essential oil of O.odorifera (Cansian et al., 2010) presented antibacterial activity against $E$. faecalis, $S$. aureus, $S$. epidermidis, $E$. coli and K. pneumoniae, which was considered more effective than the bacteria gram-negative comparisons of inhibition concentrations. Another species used in the antibacterial assay was O.notata (Garrett et al., 2007), where essential oil activity of the species showed an inhibition power for E. faecalis, $S$. aureus and $S$. epidermidis.

\section{Preliminary toxicological activities}

\section{Toxicity against Aedes aegypti and Brine shrimp lethality assay}

The essential oil was submitted to tests against 3rd stage Aedes aegypti larvae. The results (Table III) suggest that the toxicity of this fraction occurred owing to the presence of apolar compounds, terpenes and derivates, which have demonstrated larvicidal activity, however, the action mechanism was not completely elucidated (Shaalan et al., 2005; Gosh, Chowdhury, Chandra, 2012).

Ocotea nutans essential oil had positive toxicity in Aretmia salina (Table III). Based on a study by Meyer et al. (1982), samples are considered toxic with $\mathrm{LC}_{50}<1000$

TABLE II - Antioxidant activity by phosphomolybdenum and complex prussian blue

\begin{tabular}{lcc}
\hline Antioxidant activity (AA) & Phosphomolybdenum & Complex prussian blue \\
\hline AA in relation to rutin (\%) & 41,88 & 58,42 \\
AA in relation to ascorbic acid (\%) & 15,14 & 59,74 \\
\hline
\end{tabular}

The total antioxidant activity is considered to be $100 \%$ in relation to the antioxidant potential of ascorbic acid and rutin 
TABLE III - Toxicological activities against Aedes aegypti and Artemia salina

\begin{tabular}{|c|c|c|c|c|c|c|c|}
\hline \multicolumn{4}{|c|}{ Aedes aegypti } & \multicolumn{4}{|c|}{ Artemia salina } \\
\hline $\begin{array}{c}\mathrm{LC}_{50}(\mu \mathrm{g} / \mathrm{mL}) \\
(\mathrm{LCL}-\mathrm{UCL})\end{array}$ & $\begin{array}{c}\mathrm{LC}_{90}(\mu \mathrm{g} / \mathrm{mL}) \\
(\mathrm{LCL}-\mathrm{UCL})\end{array}$ & $\mathbf{x}^{2}$ & (df) & $\begin{array}{c}\mathrm{LC}_{50}(\mu \mathrm{g} / \mathrm{mL}) \\
(\mathrm{LCL}-\mathrm{UCL})\end{array}$ & $\begin{array}{c}\mathrm{LC}_{90}(\mu \mathrm{g} / \mathrm{mL}) \\
(\mathrm{LCL}-\mathrm{UCL})\end{array}$ & $\mathbf{x}^{2}$ & (df) \\
\hline $\begin{array}{c}250 \mu \mathrm{g} / \mathrm{mL} \\
(179,86-32,75)\end{array}$ & $\begin{array}{c}744,32 \mu \mathrm{g} / \mathrm{mL} \\
(534,41-1254,67)\end{array}$ & 3,355 & $(2)$ & $\begin{array}{c}71,70 \mu \mathrm{g} / \mathrm{mL} \\
(61,22-83,91)\end{array}$ & $\begin{array}{c}117,49 \mu \mathrm{g} / \mathrm{mL} \\
(97,30-170,99)\end{array}$ & 1,08 & (4) \\
\hline
\end{tabular}

No mortality was observed in the negative controls; positive control killed $100 \%$ larvae in $\mathrm{A}$. aegypti; $\left(\mathrm{LC}_{50}\right)$ lethal concentration that kills $50 \%$ of the exposed organisms; $\left(\mathrm{LC}_{90}\right)$ lethal concentration that kills $90 \%$ of the exposed organisms; (UCL) $95 \%$ upper confidence limit; (LCL) 95\% lower confidence limit; $\left(\mathrm{x}^{2}\right)$ chi square; (df) degrees of freedom;

$\mu \mathrm{g} / \mathrm{mL}$. However, Amarante et al. (2011), described a relationship between the degree of toxicity in Artemia salina and the correlation of the more detailed $\mathrm{LC}_{50}$ indicating that samples below $\left(\mathrm{LC}_{50}<100 \mu \mathrm{g} / \mathrm{mL}\right)$ are considered highly toxic. Garrett et al. (2007) performed a bioassay with O.notata essential oil where a $\mathrm{LC}_{50}$ of $2.73 \mu \mathrm{g} / \mathrm{mL}$, was considered extremely toxic.

The toxic potential of essential oils from species of Lauraceae to Artemia salina is well documented in the literature. The brine shrimp bioassay correlates with cytotoxicity in solid tumors and activity against Trypanosoma cruzi; (Mclaughlin, Rogers, Anderson, 1998; Alves et al., 2000).

The lethal concentration $\left(\mathrm{LC}_{50}\right)$ of sodium dodecylsulfatein Artemia salina should be contained in the range of 13.1 to $30.9 \mu \mathrm{g} / \mathrm{mL}$ in $24 \mathrm{~h}$ (Nascimento, Souza, Nipper, 2002), which was confirmed in the results obtained in the present study: $\mathrm{LC}_{50 \text { sodium dodeculsulfate }}=24.49 \mu \mathrm{g} / \mathrm{mL}$. This finding demonstrates that the sensitivity of individuals is standardized, which reduces the possibility of generating falsely exacerbated or attenuated results. The acute toxicity evaluation in Artemia salina establishes a parameter for the species, since no studies of previous ecotoxicological tests were found to establish comparisons.

\section{CONCLUSION}

Evaluation of $O$. nutans essential oil in biological activities showed a possible toxicity to Aedes aegypti and Artemia salina, although low antimicrobial activity was shown. The present study contributes to the enrichment of the data base concerning the specie O. nutans (Nees) Mez that previously was limited toonly botanical surveys, as well as revealing activities that require complementary studies.

\section{ACKNOWLEDGEMENTS}

The authors would like to thank CAPES for financial support, forest engineer Marcelo Brotto for help with the identification of the plant material, and the Department of Chemistry of the Federal University of Paraná, Brazil, for the assistance in GC-MS analysis.

\section{REFERENCES}

Adams RP. Identification of essential oils components by gas chromatography mass spectroscopy.4ed. Illinois: Allured Publishing Corporation, Carol Stream; 2007. 804p.

Alves CQ, David JM, David JPDL, Bahia MV, Aguiar RM. Métodos para determinação de atividadeantioxidante in vitro em substratos orgânicos. Quím Nova. 2010;33(10):2202-2210.

Amaral JF, Silva MIG, Aquino-Neto MR, Teixeira-Neto PF, Moura BA, Melo CTV, Araujo FL, Sousa DP, Vasconcelos PF, Vasconcelos SMM, Sousa FCF, Antinociceptive effect of the monoterpene R-(d)-limonene in mice. Biol Pharm Bull. 2007;30(7):1217-1220.

Amarante CB, Müller AH, Póvoa MM, Dolabela MF. Estudo fitoquímicobiomonitorado pelos ensaios de toxicidade frente à Artemia salina e de atividade antiplasmódica do caule de aninga (Montrichardialinifera). Acta Amaz. 2011;41(3):431-434.

Ayres MC, Brandão MS, Vieira-junior GM, Menor JCAS, Silva HB, Soares MJS, Chaves MH. Antibacterial activity of useful plants and chemical constituents of the roots of Coperniciaprunifera. Br J Pharmacogn. 2008;18(1):90-97.

Ballabeni V, Tognolini M, Bertoni S, Bruni R, Guerrini A, Rueda GM, Barocelli E. Antiplatelet and antithrombotic activities of essential oil from wild Ocoteaquixos (Lam.) Kosterm. (Lauraceae) calicesfromAmazonianEcuador. Pharmacol Res. 2007;55(1):23-30. 
Ballabeni V, Tognolini M, Giorgio C, Bertoni S, Bruni R, Guerrini A, Barocelli E. Ocoteaquixos Lam. essential oil: In vitro and in vivo investigation on its anti-inflammatory properties. Fitoterapia. 2010,81(4):289-295.

Barbosa-Filho, JM, Cunha RM, Dias CS, Athayde-Filho PF, Silva MS, Cunha EVL, Machado MIL, Craveiro AA, Medeiros IA. GC-MS analysis and cardiovascular activity of the essential oil of Ocoteaduckei. Ver Bras Farmacog. 2008;18(1):37-41

Brasil. Farmacopéia Brasileira. 5 ed. v. 1. Agência Nacional de Vigilância Sanitária. Brasília: ANVISA; 2010.

Brielmann HL, Setzer WN, Kaufman PB, Kirakosyan A. Phytochemicals: The chemical components of plants. Natural products from Plants. 2 ed. London: Taylor \& Francis Group; 2006. p.10-19.

Brotto ML, Cervi AC, Santos EP. O gênero Ocotea (Lauraceae) no estado do Paraná, Brasil. Rodriguésia. 2013;64(3):495-525.

Bruni R, Medici A, Andreotti E, Fantin C, Muzzoli M, Dehesa M, Sacchetti G. Chemical composition and biological activities of Ishpingo essential oil, a traditional Ecuadorian spice from Ocoteaquixos (Lam.) Kosterm.(Lauraceae) flower calices. Food Chem. 2004;85(3):415-421.

Cansian RL, Mossi AJ, Paroul N, Toniazzo G, Zboralski F, Prichoa, FC, Lerin LA. Atividade antioxidante e antimicrobiana de extratos de canela-sassafrás (Ocotea odorífera (Vell.) Rowher). Perspectiva. 2010;34(127):123-133.

Castellani DC, Casali VWD, Souza AL, Cecon PR, Cardoso CA, Marques VB. Produção de óleo essencial em canela (Ocotea odorifera Vell.) e guaçatonga (CaseasylvestrisSwartz) em função da época de colheita. Ver Bras Plantas Med. 2006;8(4):104-107.

Castro HG, Ferreira FA, Silva DJH, Mosquim PR. Contribuição ao estudo das plantas medicinais: metabólitos secundários. 2. ed. Visconde do Rio Branco: [s.e.]; 2004. p. 49.

Chaverri C, Díaz C, Cicció J. Chemical analysis of essential oils from Ocoteagomezii W.C. Burger and Ocotea morae Gómez-Laur. (Lauraceae) Collected at for natural products with antimicrobial activity: A review of the literature. J Ethnopharmacol. 2011;23:127-129.

Clinical and Laboratory Standards Institute. Methods for dilution antimicrobial susceptibility tests for bacteria that grow aerobically.M07-A8, Wayne, PA, USA: CLSI; 2008.
Constantin MB, Sartorelli P, Limberger R, Henriques AT, Steppe M, Ferreira MJP, Ohara MT, Emerenciano VP, Kato MJ. Essential oils from Piper cernuum and Piper regnellii: antimicrobial activities and analysis by CG/MS and C-NMR. Planta Med. 2001;67(8):771-773.

Coutinho DF, Dias CS, Barbosa-Filho, JM, Agra MF, Martins RM, Silva MS, Cunha EVL, Silva MS, Craveiro AA. Composition and Molluscicidal Activity of the Essential Oil from the Stem Bark of Ocoteabracteosa (Meisn) Mez. J Essential Oil Res. 2007;19(5):482-484.

Crowell P. Monoterpenes in breast câncer chemoprevention. Breast Cancer Res Treat. 1997;46(2-3):191-197.

Darra E, Abdel-Azeim S, Manara A, Shoji K, Marechal JD, Mariotto S, Cavalieri E, Pizza C, Perahia D, Crimi M, Suzuki H. Insight into the apoptosis-inducing action of $\alpha$-bisabolol towards malignant tumor cells: Involvement of lipid rafts and Bid. Arch Biochem Biophys. 2008;476(2):113-123.

Deuschle RAN, Camargo T, Alves SH, Mallmann CA, Heinzmann BM. Fracionamento do extrato diclorometânico de Seneciodesiderabilis Vellozo e avaliação da atividade antimicrobiana. Ver Bras Farmacog. 2007;17(2):71-75.

Finney DJ. Probitanalysis.Cambridge: Cambridge University Press; 1971.

Francescato LN. Constituintes de Senecioheterotrichius DC.: Isolamento, elucidação estrutural, derivatizações e avaliação da atividade antimicrobiana; estudo dos constituintes voláteis de outras espécies de Senecio. [dissertation] Santa Maria. Universidade Federal de Santa Maria, 2007.

Fujiwara GM, Annies V, de Oliveira CF, Lara RA, Gabriel MM, Betim FCM, Nadal JM, Farago PV, Dias JF, Miguel OG, Miguel MD, Marques FA, Zanin SM. Evaluation of larvicidal activity and ecotoxicity of linalool, methyl cinnamate and methyl cinnamate/linalool in combination against Aedesaegypti. Ecotoxicol Environm Saf.2017;139:238-244.

Garrett R, Cruz RA, Guerra MS, Gattuso M, Rocha L. Atividade antibacteriana do óleo essencial de Ocoteanotata guiada pelo ensaio de toxidade sobre Artemia salina Leach. Bol Latinoamer Caribe Plantas Med Aromaticas (BLACPMA). 2007;6(6):344345.

Gosh A, Chowdhury N, Chandra G. Plant extracts aspotential mosquito larvicides. Indian J Med Res. 2012;135(5):581-589. 
Grzybowski A, Tiboni M, Silva MAN, Chitolina RF, Passos M, Fontana J. The combined action of phytolarvicides for the control of dengue fever vector, Aedesaegypti. Rev Bras Farmacog. 2012;22(3):549-557.

Hirota R, Roger NN, Nakamura H, Song HS, Sawamura M, Suganuma, N. Anti-inflammatory effects of limonene from Yuzu (Citrus junos Tanaka) essential oil on eosinophils. J Food Sci. 2010;75(3):87-92.

Jayanthi P,Lalitha P. Reducing power of the solvent extracts of Eichhorniacrassipes (mart.)Solms. Int J Pharm Pharm Sci.2011;3(Suppl 3):126-128.

Lima JB, Pereira, CM, Carneiro RS, Galardo, AKR, Soares SS, Braga IA, Ramos RP, Valle D. Resistanceof Aedes aegypti toorganophosphates in severalmunicipalities in thestateof Rio de Janeiro and Espirito Santo, Brazil. Am J Trop Med Hyg. 2003;68(3):329-333.

Limberger RP, Sobral M, Henriques AT, Menut C, Bessière JM. Óleos voláteis de espécies de Myrcia nativas do Rio Grande do Sul. Quím Nova. 2004;27(6):916-919.

Marques AC. Importância econômica da família LauraceaeLindl. FlorestaAmbiente. 2001;8(1):195-206.

Mclaughlin JL, Rogers LL, Anderson JE. The use of biological assays to evaluate botanicals. Drug Inf J. 1998;32:513-524.

Meyer BN, Ferrigni NR, Putnam JE, Jacobsen LB, Nichols DJ, McLaughlin JL. Brine shrimp: a convenient general bioassay for active plant constituents. Planta Med. 1982;45(5):31-34.

Murali R, Saravanan, R. Antidiabetic effect of d-limonene, a monoterpene in streptozotocin-induced diabetic rats. Biomed Prev Nutrit. 2012;2(4):269-275.

Nascimento IA, Souza ECP, Nipper MG. Métodos e aplicações da ecotoxicologia marinha: a experiência brasileira. Salvador:ArtesGráficase Industria; 2002. p.111-122.

Prieto P, Pineda M, Aguilar M. Spectrophotometric quantitation of antioxidant capacity through the formation of a phosphomolybdenum complex: specific application to the determination of vitamin E. Anal Biochem. 1999;269(2):337341 .

Robbers JE, Speedie MK, Tyler VE. Pharmacognosy and pharmacobiotecnology. Porot Alegre: Ed Premier; 1997.
Rozza AL, Moraes TM, Kushima H, Tanimoto A, Marques MOM, Bauab TM, Hiruma-Lima CA, Pellizzon $\mathrm{CH}$. Gastroprotective mechanisms of Citrus lemon (Rutaceae) essential oil and its majority compounds limonene and -pinene: Involvement of heat-shock protein-70, vasoactive intestinal peptide, glutathione, sulfhydryl compounds,nitric oxide and prostaglandin E2. Chem-Biol Interact. 2011;189:82-89.

Scalco N, Ladeira AM, Lagov JHG, Young MCM, Carvalho LR. Avaliação de atividade fungitóxica e isolamento de aloaromadendrano - 4 $\alpha, 10 \beta$ - diol em Hypericumcordatum. Ver Bras Plantas Med.2014;16(3):744-749.

Simões CMO, Schenkel EP, Gosmann G, Mello JCP, Mentz LA, Petrovick PR. Farmacognosia - da planta ao medicamento. Porto Alegre/Florianópolis: Editora da UFRGS/Editora da UFSC; 2004. 1102p.

Souza AM, Armstrong L, Merino FJZ, Cogo LL, Monteiro CLB, Duarte MR, Miguel OG, Miguel MD. In vitro effects of Eugenia pyriformisCambess.,Myrtaceae: Antimicrobial activity and synergistic interactions with Vancomycin and Fluconazole. Afr J Pharm Pharmacol. 2014;8(35):862-867.

Shaalan EAS, Canyonb D, Younesc MWF, Abdel-Wahaba $\mathrm{H}$, Mansoura AH.A review of botanical phytochemicals with mosquitocidal potential. Environ Intv. 2005;31(8):1149-66.

Sylvestre M, Pichette A, Longtin A, Nagau F, Legault J. Essential oil analysis and anticancer activity of leaf essential oil of Croton flavens L. from Guadeloupe. J Ethnopharmacol. 2006;103(1):99-102.

Takaku S, Haber WA, Setzer, WN.Leaf essential oil composition of 10 species of Ocotea (Lauraceae) from Monteverde, Costa Rica.BiochemSyst Ecol.2007;35(8):525-532.

Taiz L, Zeiger, E. Fisiologia vegetal. 3. ed. Porto Alegre: Artmed; 2004.

Van der Werff H. A synopsis of Ocotea (Lauraceae) in Central America and Southern Mexico. Ann Missouri Bot Garg 2002;89(3):429-451.

Veiga Junior VF, Pinto AC. O gênero Copaifera L. Quím Nova.2002;25(2):273-286.

World Health Organization(WHO). Instructions for determiningthe susceptibility or resistance of mosquito larvae to insecticides. Geneva; 1981. 
World Health Organization (WHO).Guidelines for Laboratory and Field Testing of Mosquito Larvicides.Geneva: World Health Organization;2005.

Yen GC, Chen HY. Antioxidant activity of various tea extracts in relation to their antimutagenicity. J Agric Food Chem. $1995 ; 43(3): 27-32$.
Yamaguchi KKL. Estudos biológicos dos extratos e composição química dos óleos essenciais de espécies da família Lauraceae. [dissertation]. Manaus: Universidade Federal do Amazonas; 2011 .

Received for publication on $05^{\text {th }}$ February 2018 Accepted for publication on $02^{\text {nd }}$ May 2018 